\title{
Vulvar Granular Cell Tumor
}

National Cancer Institute

\section{Source}

National Cancer Institute. Vulvar Granular Cell Tumor. NCI Thesaurus. Code C40328.

A usually benign granular cell tumor that arises from the vulva. 